\title{
EFFECT OF MONETARY POLICY ON INDUSTRIAL GROWTH IN NIGERIA
}

\section{Uju Evans Akpunonu (PhD) and Ugochukwu Paul Orajaka (PhD)}

\author{
Department of Entrepreneurship Studies, Chukwuemeka Odumegwu Ojukwu University, \\ Nigeria.
}

Cite this article:

Uju E.A., Ugochukwu P.O. Effect of Monetary Policy on Industrial Growth in Nigeria. International Journal of Entrepreneurship and Business Innovation 4(1), 4760. DOI: $10.52589 / \mathrm{IJEBI}-$ 1Z4IYBYE.

\section{Manuscript History}

Received: 10 May 2021

Accepted: 27 May 2021

Published: 7 June 2021

Copyright (C) 2020 The Author(s). This is an Open Access article distributed under the terms of Creative Commons AttributionNonCommercial-NoDerivatives 4.0 International (CC BY-NC-ND 4.0 ), which permits anyone to share, use, reproduce and redistribute in any medium, provided the original author and source are credited.
ABSTRACT: Monetary policy is one of the regulatory measures of the government to checkmate the money supply in the economy in order to achieve the desired level of prices, employment, output, and boost the industrial sector growth. Industrialization has always constituted a major focus of development strategy and government policy. One of the engines of industrialization is enhancing manufacturing sector capacity; this study adopted manufacturing sector output to examine the effect of monetary policy on industrial growth in Nigeria between 1986 and 2019. Data for the study were collected from the CBN Statistical bulletin, 2019 edition. A multiple regression model was developed and the Ordinary Least Square (OLS) regression technique employed for data analysis. The results showed that Open Market Operation (OMO) measured by Treasury bill rate had positive and significant effect on the Nigerian Manufacturing Domestic Sector Gross Product; Cash Reserve Ratio (CRR) has a positive and significant effect on the Nigerian Manufacturing Sector Gross Domestic Product; and Monetary Policy Rate (MPR) has a negative and significant effect on the Nigerian Manufacturing Sector Gross Domestic Product. The study concludes that monetary policy is a veritable tool for enhancing industrial sector growth in Nigeria. It was recommended that the monetary authority should ensure a lower MPR that can drive up investment and thus boost growth of the industry.

KEYWORDS: Monetary Policy, Industrialization, Money Supply, Economic Growth 


\section{INTRODUCTION}

Monetary policy action is the prerogative of the central bank and monetary authorities of the country used for the management of money supply and interest rate in order to achieve macroeconomic objectives like employment, industrial growth, inflation, consumption, etc. Through monetary policy, economic activities and objectives of the country can be influenced either by expansionary or contractionary stance.

The industrial pattern of Nigeria at political independence in 1960 was that of providing agricultural raw material needs of the advanced economies, particularly of Britain. The bulk of national income was from exports of primary agricultural products. Available data shows that the share of agriculture in Gross Domestic Product (GDP) was about $63 \%$ and about $80 \%$ of export earnings of the country came from agriculture. The level of industrial activities in the country was very low and, mostly commercial activities owned and run by foreign companies. These companies engaged in trade and commerce especially in the importation and distribution of (foreign) manufactured goods. Laying a solid foundation for the development of an industrial economy for Nigeria was not part of the colonial economic policy rather making the colonies perpetual producers of primary raw materials for foreign industries and importers of manufactured goods (Egwaikhide et al, 2001 and Banjoko et al, 2012). Hence, being a major primary products producer and heavy consumer goods importer, which underlined the country's external dependence on the uncertain World markets coupled with Western experience to the effect that industrialization promotes economic growth and development faster than agriculture, industrialization was made the highest priority area for the Nigeria state shortly after political independence (Roberts and Azubuike, 2005).

Expansionary monetary policy stance is a situation whereby the monetary authority increases the supply of money in the economy with the aim of reducing the cost of money (interest rate) and stimulating economic activities. However, a contractionary policy entails the reduction in money supply which potentially increases the cost of money and slows the pace of economic activities.

The choice of any stance to be adopted by the central bank depends on the state of the economy at any time and the policy target of the government. But, finding a trade-off between the attainment of price stability and growth is often difficult. By setting annual monetary growth targets, the central bank intends to assert its commitment to price stability or inflation control. However, in reality, money growth might be consistent with economic growth but not with the stability of prices; in other words, although the economy is stimulated, inflation could at the same time escalate. Regarding achieving price stability, Bernanke, Laubach, Mishkin, and Posen (1999) emphasize that an inflation targeting country may not wring inflation out of their economies without laying itself open to costs in lost output and rising unemployment. Moreover, monetary growth might lead to achieving price stability but might not result in the attainment of accelerated growth. It is a herculean task finding a balance or trade-off between set goals (Khan \& Jacobson, 1989). Epstein (2007) asserts that limiting monetary policy exclusively to price stabilization cannot guarantee improved economic growth because low inflation does not necessarily give rise to high and steady economic growth. Over and above, the primary goal of monetary policy is to ensure that money supply is at a level that is consistent with the desired growth rate. 
Although no economy is self-sufficient, most economies of the world strive for self-reliance. The successful ones are often those that have a deepened economy with soaring economies of scale, which can take an economy steps farther from economic growth to economic development. Good infrastructural development combined with a favorable business and political environment supports the creation of value and increase in the production of goods and services. And, certainly, the monetary authorities are always there to harness the overall mechanism by formulating policies that will promote growth and stability in the economy. Although economic theory and quite a few empirical analyses support the fact that monetary policy influences output, the efficient con- duct of monetary policy is crucial (Ćorić, Perović, \& Šimić, 2012).

In attempt to facilitate industrialization in the country, over the years, different industrial policies/industrialization strategies like import substitution approach, export promotion strategy and foreign private investment led industrialization as well as policy reform measures like indigenization policy, structural adjustment programme, etc. have been formulated and implemented. There had been huge public investment in the industrial sector. Government embarked on the establishment of industries as a core project meant to provide the necessary foundation for growth of the industrial sector of the country by providing the basic engineering infrastructure for the production of raw materials, spare parts, equipment components and machinery needed in the various industrial establishments in Nigeria. Yet, it remains doubtful whether the approach of industrial policy-making in Nigeria has indeed been successful in transforming the economy.

\section{LITERATURE REVIEW}

\section{Monetary Policy}

Monetary policy deals with the discretionary control of money supply by monetary authority $(\mathrm{CBN})$ and fiscal authority in an attempt to attain the desired economic goals (Nuhu, 2015). Monetary policy is regarded as an effective "economic stabilizer" that is frequently applied to determine, regulate, control the quantity of money, cost availability, and influence the direction of money and lending within an economy purposely to achieve some specified macroeconomic policy focus which include increased employment, balance of payment equilibrium and sustainable economic growth and development.

There are basically two kinds of monetary policy, which are expansionary and contractionary. An expansionary monetary policy is used whenever the monetary authorities decide to increase the supply of money or reduce the cost of money in the economy so as to stimulate an increase in economic activities and also to overcome depression, recession and deflationary gap (Nuhu, 2015). This can be attained with the act of buying securities in the open market, interest and discount rates reduction, reduction in reserve requirements, and relaxing of credit controls, among others. The overall impact of expansionary monetary policy is to ensure more money is in the hands of the general public. This will lead to an increase in aggregate demand, investment, savings, employment, output and economic growth, while at the same time increasing the rate of inflation. Contractionary monetary policy is opposite of an expansionary policy. A monetary policy is said to be contractionary or tight when the monetary authorities embark on policies that will reduce the volume of money supply or increase the cost of money in the economy, in order to generate a contraction in economic activities. The impact of 
contractionary policies is to reduce the general price level and curb inflation which will equally lead to a reduction in the level of investment, employment, output and economic growth (Adegbola, Fadipe \& Olajide-Arise, 2015). The regulatory authorities may switch from contractionary to expansionary policies as the need arises depending on the economic objectives, which she is giving priority. The monetary policy adopted in Nigeria has been changing from one regime to another.

\section{Money Supply}

Money supply is the total amount of all forms of money in circulation in a given country at a given period of time (Jhingan, 2005; Abdullahi, 2009). Total money supply can be grouped into three broad categories as defined by the Central Bank of Nigeria: These money $\left(\mathrm{M}_{1}\right)$ and broad money (M2) (CBN, 2003). M1 Indicates currency in circulation plus current account deposits with commercial banks while $\mathrm{M}_{2}$ is $\mathrm{M}_{1}$ plus savings and time deposits. If the apex Bank wants to curtail money supply by reducing the power of participants (Deposit Money Bank), it will increase interest rates, while in case of an expansionary monetary policy the reverse will be the case (Yunana \& Amba, 2016). There is $\mathrm{M}_{3}$ covering $\mathrm{M}_{2}$ plus near money as defined by Gurley and Shaw. However, the Central Bank of Nigeria adopts $\mathrm{M}_{2}$ definition which it refers to as total money aggregate (Akomolafe, Danladi, Babalola \& Abah, 2015).

There is excess money supply when the amount of money in circulation is higher than the level of total output of the economy. When money supply exceeds the level, the economy can efficiently absorb, it dislodges the stability of the price system, leading to inflation or higher prices of goods. Money Supply is the life wire of all economic activities and so has powerful effects on the economic life of any nation. An increase in Money Supply puts more money in the hands of producers and consumers and thereby stimulating increased investment and consumption. Consumers increase purchases and business firms respond to increased sales by ordering for more raw materials and other resources to achieve more production, the spread of business and capital goods. As the economy goes buoyant, Stock Market prices rise and firms issue more equity and debt instruments. As the Money Supply expands, prices begin to rise, especially if output growth reaches full capacity. Lenders insist on higher interest rates to offset expected decline in purchasing power over the lifespan of their loans. Opposite effects occur when the Money Supply falls or when there is decline in its growth rate, economic activities decline and disinflation (reduced inflation) or deflation (falling price) results (Umeora 2010).

The CBN changes the level of money supply to control base money. Monetary Base is made up of currency and coins outside the banking system plus the deposits of banks with the Central Bank. If the Central Bank perceives that there is too much money in circulation and prices are rising (or there is potential pressure for prices to rise), it may reduce money supply by reducing the base money. To reduce the base money, the Central Bank sells financial securities to banks and the nonbank public so as to reduce the ability of deposit money banks to create new money. The Central Bank can reduce the money supply by also raising the cash reserve deposits that banks are required to hold with the Central Bank. The larger the deposit balances on the bank balance sheet, the higher their ability to create more money. Central bank monetary policy therefore, targets the growth in those deposit balances so as to control the expansion in money supply which could precipitate price distortions. Monetary stability can contribute towards price stability in the Nigerian economy since the variation in price level is mainly caused by money supply (Mohamed \& Sri, 2016). 


\section{Monetary Policy Rate}

Monetary policy rate is the baseline interest rate that every other interest rate adds on to. The rate controls the amount of money in circulation at any given time. Monetary policy rate is set by the Apex bank of a country. Situating it in the Nigeria context, it refers to the Central Bank of Nigeria benchmark for interest rate in the Nigerian economy. It is a short term interest rate at which banks can borrow from the apex bank. The MPR was introduced by the former CBN Governor, Professor Charles Soludo in December 2006 to replace the minimum rediscount rate (MRR). A rise in the monetary policy rate will result in the shrinking of money in circulation and when you lower it, money supply will expand. The decision to tighten or loosen money supply in an economy rests on the apex bank and depends on its monetary policy focus. Monetary policy rate for Nigeria has remained at $14 \%$ since July 2016, but have been reviewed by the Central Bank of Nigeria to $13.5 \%$ in March, 2019

In the late 1970s and early 1980s, a number of central banks world-wide adopted monetary targets as a guide for monetary policy. Monetary targeting is an attempt by central banks to describe or determine the optimum money stock that will yield the desired macroeconomic objectives. Theoretically, the choice of target is normally between the stock of monetary aggregates and interest rates. Whenever the money demand function is unstable, interest rate is generally the preferred target; otherwise, the money stock is the appropriate target (McCallum, 1989). In the early 1990s, some central banks adopted numerical inflation or nominal GDP targets as guides for monetary policy in contrast to the conventional choice of interest rate or money stock. Economists and analysts attribute this departure to the unreliability of monetary aggregates as guides for monetary policy (Osakwe, Ibenta \& Nzotta, 2019).

\section{Treasury Bill Rate}

Treasury bill rate is used as a proxy for the return on the governments' debt instruments. It is expected that high Treasury bill rates can have a positive impact on commercial banks' investment in Government's instrument. Further, it is anticipated that the high Treasury bill rates could engineer upward pressure on commercial rates in the economy thereby leading to higher interest rates on loans and advances. In this regard, a positive impact is also expected on commercial banks' investment in loans. The inclusion of the Government's fiscal balance has merit in the fact that Government's debt financing activities are driven primarily by the balance on its fiscal accounts (Biza, Kapingura \& Tsegaye, 2013)

These are instruments for short term borrowing issued by the Central Bank on behalf of the Federal Government to meet its short-term treasury needs. A Treasury bill is a paperless shortterm borrowing instrument issued by the Government through the Central Bank of Nigeria (as a fiscal agent) to raise money on a short -term basis - for a period of up to 1 year. Treasury bills are issued in maturities of 91, 182 and 364 days. Treasury bills are sold at a discounted price to reflect investor's return and redeemed at face (par) value (Anthony, 2015).

\section{Cash Reserve Ratio}

Cash Reserve Ratio refers to a certain percentage of total deposits the deposit money banks are required to maintain in the form of cash reserve with the central bank. The objective of maintaining the cash reserve is to prevent the shortage of funds in meeting the demand by the depositor. The amount of reserve to be maintained depends on the bank's experience regarding the cash demand by the depositors. If there had been no government rules, the deposit money 
banks would keep a very low percentage of their deposits in the form of reserves. Since cash reserve is non-interest bearing, i.e. no interest is paid on the deposits, therefore, the deposit money banks often keep the reserve below the safe limits. This might lead to a financial crisis in the banking sector. Thus, in order to avoid such uncertainty, the central bank imposes a cash reserve ratio or CRR on deposit money banks. The central bank has the legal power to change the CRR any time at its discretion. The cash reserve ratio is a legal requirement and therefore it is also called a Statutory Reserve Ratio (SRR). Through a cash reserve ratio, the central bank can change money supply in the economy. Such as, when the economy demands a Contractionary Monetary Policy, the central bank will raise the CRR. On the other hand, when the economic conditions demand for an Expansionary Monetary Policy, the central bank cuts down the CRR.

Cash Reserve Ratio is one of the components of the monetary policy of the Central Bank of Nigeria which is used to regulate the money supply, level of inflation and liquidity in the country. The higher the CRR, the lower is the liquidity with the banks and vice-versa.

During high levels of inflation, attempts are made to reduce the money supply in the economy. For this, RBI increases the CRR, sucking the loanable funds available with the banks. This, in turn, slows down investment and reduces the supply of money in the economy. As a result, the growth of the economy is negatively impacted. However, this also helps bring down inflation.

\section{Manufacturing Sector Output}

The manufacturing sector industry played a significant role in the transformation of the economy for example; it is an avenue for increasing productivity related to import replacement and export expansion, creating foreign exchange earning capacity; and raising employment and per capita income which causes unique consumption patterns. Furthermore, Ogwuma (1995) opines that it creates investment capital at a faster rate than any other sector of the economy while promoting wider and more effective linkages among different sectors. Acknowledge this benefit of this sector; the Nigerian government has introduced various strategies to bust the sector such as import substitution strategy, export promotion strategy, the introduction of the bank of industry to induce credit facility to the sector and the National Economic Empowerment and Development Strategy (NEEDS).

Loto (2012) revealed that the Structural Adjustment Programme (SAP) introduced in May 1986 was partly designed to revitalize the manufacturing sector by shifting emphasis to increased domestic sourcing of inputs through monetary and fiscal incentives. The deregulation of the foreign exchange market was also affected to make non-oil exports especially the manufacturing sector more competitive even though this also resulted in massive escalation in input costs. Examining the manufacturing sector over the years in Nigerian economy shows that the share of the manufacturing sector in the gross domestic product has not been impressive. The manufacturing sector contributed 34.94\% to gross domestic product in 1986 after the structural adjustment programme. By 1990 and 1995 it declined to $22.84 \%$ and $10.17 \%$ respectively. The contribution of the Nigerian manufacturing sector to Gross domestic product is very insignificant between 1996 to2012. The year 2000, 2005 and 2012 recorded $6.97 \%, 2.80 \%$ and $1.88 \%$ respectively. The insignificant contribution of the sector to gross domestic product is as a result of continued deterioration in infrastructural facilities, especially the power sector. The growth rate of the manufacturing sector has not been very impressive. 
International Journal of Entrepreneurship and Business Innovation

ISSN: 2689-9493

Volume 4, Issue 1, 2021 (pp. 47-60)

www.abjournals.org

The highest growth rate was recorded in 1988 during the SAP period. In fact, negative rate was experience in 2002, 2003 and 2004

\section{Theoretical Framework}

The study is anchored on Keynesian theory which did not buy the notion that the relationship between money and price is direct and proportional. They share the view that it is indirect through the rate of interest. Also, they reject the notion that the economy is always at or near the natural level of real GDP so that Y in the equation of exchange can be regarded as fixed. They also reject the proposition that the velocity of circulation of money is constant.

Keynesians believe that expansionary monetary policy increases the supply of loanable funds available through the banking system, causing interest rates to fall. With lower interest rates, aggregate expenditures on investment, industrialization inclusive and interest-sensitive consumption goods usually increase, causing real GDP to rise. Hence, monetary policy can affect real GDP indirectly.

\section{Empirical Review}

Osakwe, Ibenta and Ezeabasili (2019) examined the effect of monetary policy on the performance of the Manufacturing sector in Nigeria. The explanatory variables are monetary policy rate, Treasury bills rate, Cash reserve requirement and money supply; while the dependent variable is the Manufacturing (MANU) sector output. The study adopted an ex-post facto research design and used secondary data obtained from the CBN Statistical Bulletin. The study covered a period of 32 years (1986 to 2017). The data were subjected to Augmented Dicker Fuller stationarity test to determine the best suitable econometric tool of analyses. The Autoregressive Distributed Lag (ARDL) was used for the model estimation. The results indicate that: monetary policy tools have a significant effect on the manufacturing sector output in Nigeria in the short run only. The study thus concludes that monetary policy tools may not be a long run policy instrument for the growth of the manufacturing sector output in Nigeria but rather short run instruments. This study recommended that money supply and treasury bills can be used in the short run as policy instruments to maintain macroeconomic stability in Nigeria with reference to the manufacturing sector.

Onwuteaka, Okoye and Molokwu (2019) chequered history of the Nigeria monetary policy has created a visible asymmetry in the two known monetary regimes (before and after SAP) in the country. Years after the Structural Adjustment Programme (SAP), the Nigeria economy grew to become the strongest economy in Africa and suddenly plunging into recession, a situation that have adversely affected the growth and development of the economy by ways of rising unemployment rate, soaring poverty and swollen external debt, thus suggesting that the failure of the monetary policy in curbing price instability has caused growth instability as Nigeria's record of growth and development has become very poor. This study therefore examines the effect of monetary policy on economic growth in Nigeria using secondary data covering the period of 1980-2017 that were sourced from the Central Bank of Nigeria statistical bulletin. The model's estimates were estimated via multiple econometric models of the ordinary least squares to ascertain the effect of money supply, credit in the economy, interest rate on credit, infrastructure, inflationary rate, external debts, price index on growth in Nigeria. The results show that money supply, interest rate on credit, infrastructure and external debt were statistically significant in explaining its impacts on economic growth while other variables used in the study were all found to be statistically insignificant in explaining the 
growth rate of the Nigerian economy. The study recommends among others that for effective operation of the monetary policy measures in the Nigerian economy, the Central Bank of Nigeria should be granted full autonomy on its monetary policy functions. Partial autonomy should be replaced with full autonomy for the central banks in the developing economies at large which is invariably subjected to government interference and its politics.

Shobande (2019) examines the impact of switching from direct to indirect monetary policy on industrial growth in Nigeria, using the annual time series data sourced from the Central Bank of Nigeria's (CBN) statistical bulletin between 1960 and 2015. The study adopts the Autoregressive Distributed Lag (ARDL) bound testing approach developed by Pesaran, Shin and Smith (2001) for estimating the relevant relationships. The result of the long-run estimates shows that domestic credit, interest rate and trade balance have positive impact on industrial output while money supply, inflation and exchange rate have negative impact on industrial growth. The result of the short-run dynamics shows that change in the previous (one and second lagged) periods of indirect monetary policy (interest rate, money supply, domestic credit and exchange rate) and industrial output were negatively related to change in industrial output. The error correction term indicates the speed of adjustment of equilibrium to their long- run position, which was found to be negative and significant. The study recommends that policy makers use both conventional and non-conventional monetary policies to speed up industrial output growth and enhance economic recovery by manipulating the macro-economic fundamentals.

Ashamu (2020) investigated the impact of monetary policy on foreign trade in Nigeria during the period 1981 to 2017. The research made use of secondary data which are collected from the Central Bank of Nigeria, Statistical Bulletin (2017). The model obtained from the result represents an Error Correction Model (ECM) which relates the dependent variable (Net Import) to several predictor variables: Money Supply, Interest Rate, Exchange Rate, Foreign Direct Investment and Trade Openness. From the findings of the study, the error correction term (speed of adjustment towards equilibrium) value of -0.53581 is significant at $5 \%$ and implies that there is a long run causality running from monetary policy activities measures of foreign trade. However, only all the variables used in the study were significant at 5\% level of significance. This implies that monetary policy in Nigeria has a positive influence on foreign trade within the period, except for interest rates that have a negative coefficient and are not significant. In conclusion, these intermediate variables of monetary exchange rate arguably have a huge impact on the economy because of its effect on the value of local currency, domestic inflation, macroeconomic credibility, capital flows and financial stability. Increased exchange rate directly affects the prices of imported commodities and an increase in the price of imported goods and services contributes directly to increase in inflation. Based on the analysis, the study concluded that there is a significant relationship between money supply and net import in Nigeria and also that there is relationship between foreign direct investment and net import in Nigeria. The study also shows that there is a relationship between trade openness and net import in Nigeria.

Hammed (2020) investigates the impact of monetary policy shock on the manufacturing output in Nigeria using time series data covering the period between 1981 and 2018. Co-integration test was used to establish the long run relationship among the variables and Structural Vector Auto-Regressive model was employed to test for the shocks. It was found that shock to broad money supply would bring about a positive and significant impact on the manufacturing output while the impact of shock to interest rate was found to be negative and insignificant. This study 
however concludes that shock to broad money is the main monetary policy instrument which can bring about positive change to manufacturing output in Nigeria. This paper then suggests that government and policy makers should primarily focus on this variable in their implementation of unanticipated monetary policy.

Nwoko, Ihemeje and Anumadu (2016) examined the extent to which the Central Bank of Nigeria Monetary Policies could effectively be used to promote economic growth, covering the period of 1990- 2011. The influence of money supply, average price, interest rate and labour force were tested on Gross Domestic Product using the multiple regression models as the main statistical tool of analysis. Studies show that CBN Monetary Policy measures are effective in regulating both the monetary and real sector aggregates such as employment, prices, level of output and the rate of economic growth. Empirical findings from this study indicate that average price and labour force have significant influence on Gross Domestic Product while money supply was not significant. Interest rate was negative and statistically significant. It is therefore recommended that Central Bank Monetary Policy could be an effective tool to encourage investment, reduce unemployment, reduce lending rate and stabilize the economy of Nigeria.

Ezeaku, Ibe, Ugwuanyi, Modebe and Agbaeze (2018) assess the industry effects of monetary policy transmission channels in Nigeria within the period 1981-2014. Techniques of analysis employed in the study are the Johansen cointegration and the error correction model (ECM). Our regression estimates reveal that the private sector credit, interest rate, and exchange rate channels have negative effects on real output growth, both in the long run and in the short run. The results further show that, relatively, the degrees of the established effects are higher in the long run than in the short run. We employed the Johansen cointegration approach to determine the nature of the relationship that exists between our dependent variable and the independent variables. The results show that, in the Nigerian case, monetary policy transmission channels jointly have a long-run relationship with real output growth of the industrial sector, and disequilibrium in the system is corrected at the speed of $72.2 \%$ annually.

Ayodeji and Oluwole (2018) examined the impact of monetary policy on economic growth in Nigeria by developing a model that is able to investigate how monetary policy of the government has affected economic growth through the use of multi-variable regression analysis. We proxied the variables of monetary policy instruments to include: Money Supply (MS), Exchange Rate (ER), Interest Rate (IR), and Liquidity Ratio (LR). Economic growth was represented by Gross Domestic Product (income) at constant prices. Unit root test was con- ducted and all our estimating variables were stationary at first difference except the component of interest rate which shows that our model interpretation would not be spurious and a true representation of the relationships that exists between the explained and explanatory variables. The Error Correction Model was introduced in our estimation in order to have a parsimonious model. From our result, two variables (money supply and exchange rate) had a positive but fairly insignificant impact on economic growth. Measures of interest rate and liquidity ratio on the other hand, had a negative but highly significant impact on economic growth which supports the assertion by Busari et al. (2002) that monetary policies are better suited when they are used in targeting inflation rather than in stimulating growth. In addition, the Engle-Granger cointegration test was done and showed the existence of a long run relationship between monetary policy and economic growth in Nigeria. Finally, granger causality test was done on our variables and the results showed the existence of a unidirectional causality between money supply and economic growth, economic growth granger causing liquidity ratio 
and exchange rates while a bi-directional causality exists between interest and economic growth. We recommend that partial autonomy should be replaced with full autonomy for the central banks in Nigeria which is invariably subjected to government interference and its politics. Finally, monetary policies should be used to create a favorable investment climate by facilitating the emergency of market based interest rate and exchange rate regimes that attract both domestic and foreign investments.

Adigwe, Echekoba and Onyeagba (2015) examines the impact of monetary policy on the Nigerian economy. In doing this, the Ordinary Least Square Method (OLS) is used to analyse the data between 1980 and 2010. The result of the analysis shows that monetary policy represented by money supply exerts a positive impact on GDP growth but negative impact on the rate of inflation. The recommendations are that monetary policy should facilitate a favourable investment climate through appropriate interest rates, exchange rate and liquidity management mechanism and the money market should provide more financial instruments that satisfy the requirements of the ever-green sophistication of operators.

Oguda and Chinda (2017) examined commercial banks' lending activities and economic growth in Nigeria. They posit that lending is undoubtedly the heart of banking business, and therefore, the administration of lending requires bank management to employ skill and dexterity in policy formulation and application that would guarantee reasonable income and adequate liquidity while ensuring safety of bank's funds.

Ufoeze, Odimgbe, Ezeabalisi, and Alajekwu (2018) investigated the effect of monetary policy on economic growth in Nigeria. The natural log of the GDP was used as the dependent variables against the explanatory monetary policy variables: monetary policy rate, money supply, exchange rate, lending rate and investment. The time series data is the market-controlled period covering 1986 to 2016. The study adopted an Ordinary Least Squares technique and also conducted the unit root and co-integration tests. The study showed that a long run relationship exists among the variables. In addition, the core finding of this study showed that monetary policy rate, interest rate, and investment have insignificant positive effects on economic growth in Nigeria. Money supply however has a significant positive effect on growth in Nigeria. Exchange rate has a significant negative effect on GDP in Nigeria. Money supply and investment granger cause economic growth, while economic growth causes interest rate in Nigeria. On the overall, monetary policy explains $98 \%$ of the changes in economic growth in Nigeria. Thus, the study concluded that monetary policy can be effectively used to control Nigerian economy and thus a veritable tool for price stability and improved output.

\section{METHODOLOGY}

\section{Research Design}

The study used ex-post facto research design. Secondary data were sourced through Central Bank of Nigeria (CBN) Statistical Bulletin, 2019 edition. It is an annual time series data covering 1986 to 2019. 


\section{Model Specification}

The present study modified the work of Owolabi and Adegbite (2014), using manufacturing sector output as dependent variable, while the explanatory variables were adapted to the model using monetary policy rate, Treasury bills rate, then this study introduced Cash reserve requirement, and controlled by money supply. However, deposit and lending rates were removed from this study. Thus the modified Monetary Policy Tools and Manufacturing Model is:

$\mathrm{MANU}=\mathrm{f}(\mathrm{TBR}, \mathrm{CRR}, \mathrm{MPR})$ 1

The equation form of the model is

$\mathrm{MANU}=\mathrm{b}_{0}+\mathrm{b}_{1} \mathrm{TBR}+\mathrm{b}_{2} \mathrm{CRR}+\mathrm{b}_{3} \mathrm{MPR}+\varepsilon$ .2

Where:

MANU $=\quad$ Contribution of manufacturing subsector output to Gross Domestic Product.

$\mathrm{CRR}=\quad$ Cash Reserve Ratio

MPR $=\quad$ Monetary policy rate

$\mathrm{TBR}=\quad$ Treasury Bill Rate

$\mathrm{b} 0=\quad$ The constant

$\mathrm{b} 1-\mathrm{b} 4=\quad$ The coefficients of the explanatory variables

$\varepsilon=\quad$ Error term.

\section{Method of Analysis}

A simple regression analysis was done using the Ordinary Least Square technique.

\section{Data Analysis And Interpretation}

\section{Presentation of Data}

The data for the analysis were shown on Appendix 1. The variables include manufacturing sector contribution to the Gross Domestic Product (MANU), Monetary Policy Rate (MPR), Treasury Bill Rate (TBR), and Cash Reserve Ratio (CRR). The data were collected from the CBN Statistical Bulletin. It covered a time period of 34 years from 1986 to 2019.

Table 1: Descriptive Statistics of the Variables

\begin{tabular}{|l|r|r|r|}
\hline & \multicolumn{1}{|c|}{ Mean } & Std. Deviation & \multicolumn{1}{|c|}{$\mathrm{N}$} \\
\hline MAN & 8.2070 & .95702 & 34 \\
U & & & 34 \\
MPR & 12.5500 & 3.32514 & 34 \\
TBR & 66.5755 & 140.12855 & 34 \\
CRR & 10.8650 & 10.00464 & \\
\hline
\end{tabular}


International Journal of Entrepreneurship and Business Innovation

ISSN: 2689-9493

Volume 4, Issue 1, 2021 (pp. 47-60)

www.abjournals.org

The mean of the MANU is N8.21 billion with a standard deviation of N0.96 billion. The mean of MPR is at a rate of $12.55 \%$ and standard deviation of $3.32 \%$; and that of the Treasury Bill Rate which measures Open Market Operation is a mean of $66.58 \%$ and standard deviation of $140.13 \%$. As for the CRR, the mean and standard deviation are $10.87 \%$ and $10.0 \%$ respectively.

Table 2: Results of OLS Regression

\begin{tabular}{|c|c|c|c|c|c|c|}
\hline \multirow{2}{*}{\multicolumn{2}{|c|}{ Model }} & \multicolumn{2}{|c|}{ Unstandardized Coefficients } & \multirow{2}{*}{$\begin{array}{c}\text { Standardized } \\
\text { Coefficients } \\
\text { Beta } \\
\end{array}$} & \multirow[t]{2}{*}{$\mathrm{T}$} & \multirow[t]{2}{*}{ Sig. } \\
\hline & & $\mathrm{B}$ & Std. Error & & & \\
\hline \multirow{4}{*}{1} & (Constant) & 8.997 & .545 & & 16.522 & .000 \\
\hline & MPR & -.121 & .043 & -.420 & -2.789 & .013 \\
\hline & TBR & .003 & .001 & .422 & 2.512 & .023 \\
\hline & CRR & .049 & .016 & .514 & 3.015 & .008 \\
\hline \multicolumn{7}{|c|}{$\begin{array}{l}\text { Coefficient of Determination }(\mathrm{R} \text { Squared })=0.662 \\
\text { F-Statistics }=10.433 \\
\text { P.value }=0.000\end{array}$} \\
\hline
\end{tabular}

a. Dependent Variable: MANU

The result on Table 2 is used to answer the research questions and test the hypothesis posed for the study. The overall result is explained using the coefficient of determination and tested using the ANOVA (F-statistics). The specific objectives are addressed using the coefficients of regression and tested using the t-statistics.

The result of the coefficient of determination $\left(\mathrm{R}^{2}\right)$ is 0.662 which indicates that about $66 \%$ of changes in industrial sector growth can be explained by changes in monetary policies (MPR, TBR, CRR) in Nigeria. This suggests that monetary policies account for a huge chunk of industrial sector growth drivers in Nigeria.

The ANOVA (F-statistics) value is 10.433 with probability (significance) value of 0.000 . Since the p.value is less than 0.05 level of significance, it means that the outcome of the coefficient of determination $\left(\mathrm{R}^{2}\right)$ is statistically significant. This study posits that monetary policy has a significant effect on industrial sector growth in Nigeria.

The specific objectives shows that model outcome to be as follows:

$$
\begin{aligned}
& \text { MANU }=b_{0}+b_{1} \mathrm{TBR}+\mathrm{b}_{2} \mathrm{CRR}+\mathrm{b}_{3} \mathrm{MPR}+\varepsilon \\
& \mathrm{MANU}=8.997+.003 \mathrm{TBR}+.049 \mathrm{CRR}-.121 \mathrm{MPR}
\end{aligned}
$$

\section{Discussions on the Results}

The coefficient of regression for OMO measured by Treasury Bill Rate (TBR) is .003 TBR. This indicates that there is a positive relationship between Treasury Bill Rate and industrial sector growth as measured by manufacturing sector output in Nigeria. This means that a unit increase in TBR is expected to lead to an increase in industrial sector growth. This is used to answer the research question of "Does the Open Market Operation (OMO) have an impact on the Nigerian Manufacturing Sector Gross Domestic Product (MGDP)?" The study answered 
International Journal of Entrepreneurship and Business Innovation

ISSN: 2689-9493

Volume 4, Issue 1, 2021 (pp. 47-60)

www.abjournals.org

that Open Market Operation measured by Treasury Bill Rate has a positive effect on Manufacturing Sector Gross Domestic Product in Nigeria.

The coefficient of regression for cash reserve ratio (CRR) is 0.049CRR. This indicates that there is a positive relationship between cash reserve ratio and industrial sector growth as measured by manufacturing sector output in Nigeria. This means that a unit increase in CRR is expected to lead to an increase in industrial sector growth. This is used to answer the research question of "Does the Cash Reserve Ratio (CRR) have an impact on the Nigerian Manufacturing Sector Gross Domestic Product (MGDP)?" The study answered that Cash Reserve Ratiohas a positive effect on Manufacturing Sector Gross Domestic Product in Nigeria.

The coefficient of regression for the Monetary Policy Rate (MPR) is -.121MPR. This indicates that there is a negative relationship between Monetary Policy Rate (MPR) and industrial sector growth as measured by manufacturing sector output in Nigeria. This means that a unit increase in MPR is expected to lead to a fall in industrial sector growth. This is used to answer the research question of "Does the Cash Reserve Ratio (CRR) have an impact on the Nigerian Manufacturing Sector Gross Domestic Product (MGDP)?" The study answered that Cash Reserve Ratio has a positive effect on Manufacturing Sector Gross Domestic Product in Nigeria.

\section{Conclusion And Recommendations}

Monetary policy is a veritable tool for enhancing industrial sector growth in Nigeria. Monetary policy rate with a negative effect is a sound tool for increasing investment with low MPR and boosting growth of the industry. Cash reserve and treasury bill is effective in controlling cost of funds and managing the investment in the industrial sector in Nigeria.

The following recommendations are posed for the study:

1. It is recommended that the monetary authority should ensure a lower MPR that can drive up investment and thus boost growth of the industry.

2. The government should encourage the use of OMO to enhance availability of money in circulation to boost industrial sector productivity and growth.

\section{REFERENCES}

Adegbola, E.A., Fadipe, T.G. \& Olajide, A.T. (2015). Monetary theory and policy. Department of Banking and Finance. Lagos: National Open University of Nigeria.

Adigwe, P.K., Echekoba, F.N, \& Onyeagba, J.B.C. (2015). Monetary Policy and Economic Growth in Nigeria: A Critical Evaluation. IOSR Journal of Business and Management 17(2) $110-119$

Ashamu, S.O. (2020). The Effect of Monetary Policy on Foreign Trade in Nigeria. Australian Finance \& Banking Review 4(1)

Ayodeji, A. \& Oluwole, A. (2018). Impact of Monetary Policy on Economic Growth in

Nigeria. Open Access Library Journal, 5: e4320. 
International Journal of Entrepreneurship and Business Innovation

ISSN: 2689-9493

Volume 4, Issue 1, 2021 (pp. 47-60)

www.abjournals.org

Bernanke, B. S., Laubach, T., Mishkin, F. S., \& Posen, A. S. (1999). Inflation targeting: Lessons from the international experience. Princeton, NJ: Princeton University Press.

CBN (2008). Central Bank of Nigeria (CBN), Monetary Policy Department Series 1, 2008.CBN/MPD/Series/01/2008

Ćorić, B., Perović, L. M., \& Šimić, V. (2012, June 27). Monetary policy effects on output and prices: International evidence. The young economists' seminar to 18th Dubrovnik Economic Conference organised by Croatian National Bank, University of Split, Faculty of Economics, Croatia.

Epstein, G. (2007). Central banks, inflation targeting and employment creation (Economic and Labour Market Paper 2007/2).

Ezeaku, H.C., Ibe, I.G., Ugwuanyi, U.B., Modebe, N.J. \& Agbaeze, E.K (2018). Monetary Policy Transmission and Industrial Sector Growth: Empirical Evidence from Nigeria. SAGE; $1-12$

Hammed, Y.S. (2020). Monetary Policy Shock and Manufacturing Output in Nigeria (19812018). Advance Journal of Social Science 7(1); 27-37

Khan, G. A., \& Jacobson, A. (1989). Lessons from West German monetary policy. Economic Review, 74, 18-35.

Nuhu, K.M. (2015). An analysis of the impacts of monetary policy on Nigerian economy. Journal of Economics and Sustainable Development, 6 (20), 129-133

Nwoko, N.M., Ihemeje, J. C.\& Anumadu, E. (2016). The Impact of Monetary Policy on the Economic Growth of Nigeria. An International Multi-disciplinary Journal, Ethiopia 10(3): 192-206

Oguda, F\& Chinda, O. (2018). Monetary policy and credit condition: Evidence from the Money Market. Journal of Finance and Banking, 25(6), 166-183.

Onwuteaka, I.C., Okoye, P.V.C \& Molokwu, I.M. (2019). Effect of Monetary Policy on economic growth in Nigeria. International Journal of Trend in Scientific Research and Development, 3(3), 590-597.

Osakwe, A., Ibenta, S. N. ., \& Ezeabasili, V. N. (2019). Monetary Policy and the Performance of the Manufacturing Sector in Nigeria (1986-2017). International Journal of Academic Research in Business and Social Sciences, 9(2), 399-413

Owolabi, A. U \& Adegbite, T. A. (2014). Impact of monetary policy on industrial growth in Nigeria. International Journal of Academic Research in Business and Social Sciences, $4(1), 18-31$.

Shobande, O.A. (2019). Monetary policy spillovers through industrial growth in Nigeria: a time series analysis. Economics and Business 33, 94-110

Udeala, S. (2002). Manufacturers and the new interest rate regime. www.economicconfidential.com Browsed on 20th July, 2009.

Ufoeze, L.O., Odimgbe, S. O., Ezeabalisi, V. N. and Alajekwu, U.D (2018). Effect of Monetary Policy on Economic GrowthIn Nigeria: An Empirical Investigation. Annals of Spiru Haret University, Economic Series. Issue 1 